\title{
Effects of landscape evolution stages on soil properties distribution in Yancheng National Nature Reserve, China
}

\author{
Yufeng $\mathrm{Li}^{1}$, Juan Wang ${ }^{2}$ and Hongyu Liu ${ }^{1, *}$ \\ ${ }^{I^{*}}$ Jiangsu Center for Collaborative Innovation in Geographical Information Resource Development and \\ Application, Key Laboratory of Virtual Geographic Environment (Ministry of Education), \\ State Key Laboratory Cultivation Base of Geographical Environment Evolution, College of Geographical \\ Science, Nanjing Normal University, Nanjing 210023, China. \\ ${ }^{2}$ School of Urban and Planning, Yancheng Teachers University, Yancheng 224007, China.
}

Corresponding author: liuhongyu@njnu.edu.cn

\begin{abstract}
A typical wetland in the core area of Yancheng National Nature Reserve was chosen as study area. Using three periods of remote sensing images in 1992, 2002 and 2011, different successional stages of landscape have been discerned. And then by employing a space-for-time substitution approach, related environmental factors of soil was analyzed. The analysis results showed that the landscape types and its successional time were the important factors that influenced the spatial distributions of soil characteristic. The detailed results revealed: (1) The Spartina marsh succession time was longer, more reduction effect of soil water and salt content, more with the accumulation effect on soil nutrients; (2) The Suaeda marsh succession time was longer, more accumulation of soil water and salt content, more with the weakening effect on soil nutrients; (3) The moisture, salinity of soil decreased more and more, soil nutrient increased more and more as the grass marsh existed longer time. This study could help us to evaluate the degradation of wetland and the effect of wetland restoration, as well as to help us to achieve the balance between utilization and reservation.
\end{abstract}

Keywords: Landscape evolution, coastal wetland, space-for-time substitution, soil properties, Yancheng National Nature Reserve

\section{Introduction}

Yancheng National Nature Reserve (YNNR) is one of the most important landscape evolution of China and one of the most complex typical muddy coastal wetlands in the world ecosystem type. The YNNR is one of the world's major winter habitats for red-crowned cranes. It is also a stop-over site for over 300 species of migratory birds from Northeast Asia and Australia (Zhu et al. 2004). So, the habitat of those birds need to be focused, especially the change of its landscape. Currently, studies into the evolution process of coastal wetlands, ecosystem health and reconstruction and ecosystem service values are at the forefront of national wetland research (Sean 2002; Roychoudhury et al. 2003; Zhang et al. 2013). The YNNR has attracted attention from scholars since the 1980s (Zhu and Xu 1982; Zhu et al. 2004) for studies into topography, sedimentation, hydrology, ecology, sustainable development and evolution of landscape (Zhang 1986; Zhang 1991; Shen et al. 2006). The study of landscape evolution which related to ecological process in YNNR is sorely lacked. Although some studies noted the effects of hydrogeomorphologic processes on wetland landscape in coastal area (Gao et al. 2005; 
Yao et al. 2009), research results in the relationships between soil processes and the evolution of landscape are very limited.

On the issues of landscape evolution, most of researches focus on identifying the landscape evolution of time and space dynamic using remote sensing methods (Clarkson 1998; Odland 2002; Bender 2005), and landscape evolution is one of the main factors that control the soil properties (Gamboa and Galicia 2011). Vegetaion changes in the landscape can make effective on soil charicteristics and soil charicteristics as a reaction will be on vegetation. Vegetation changes under the forces of nature (not due to human activity) in landscape can be regarded as landscape evolution. Although many studies have focused on the effect of different landscape evolution on the soil properties, the effects of landscape conversion on the soil properties are not fully understood due to the variability of tillage systems and the shortage of historical soil data (Pellegrino et al. 2011). It is generally accepted that the dynamics of landscape is best studied by long-term observations and experiment (Gosz 1996). With regard to soil data shortages, remote sensing, and geographical information system are typically used to identify the changes in landscape and soil properties (El-Shikha et al. 2007), as well as the spatial variability of soil properties in ecosystems (Grunwald et al. 2007). Appropriate space-for-time substitution (SFT) can aid planning of observations and experiments for further study.

The vegetation landscape-soil system, a part of the coastal ecosystem, is a dramatically dynamic and developmental process (Ouyang et al. 2013). The soil develops continuously to reach a balance that relates with vegetation climax along the vegetation landscape succession (Zhang et al. 1990). A quantitative investigation of the soil characteristic evolution and its mechanism in terms of landscape evolution is vital to the study of the development tendency of the coastal system ( $\mathrm{Li}$ et al. 2013). The core area of YNNR was chosen as the study area to provide a scientific foundation for constructing the eco-environment and rehabilitating the water storing and regulating capacity of the soil. The intact series in the natural landscape evolution on coastal area can be found in this area. The soil characteristics at different landscape evolution stages can be analyzed by SFT in YNNR. Through the collection and analysis of soil samples, the relationship of the process of landscape succession and soil factors can be obtained in YNNR. It provides an in-depth understanding and the basic reference of the coastal wetland ecosystem in the process of succession.

\section{Materials and methods}

\section{Study area}

The Yancheng coastal marshes are located in the coastal zone of Jiangsu Province, East China (Fig.1). In 1983, YNNR was established to help conserve rare bird species and their habitats. As the marsh area has a rich biodiversity, YNNR was accepted as a member of the UNESCO Man and Biosphere Reserve network in 1993 and was admitted as Northeast Asian Crane Reserve Network Site in 1997 and as an East Asia-Australian Migratory Shorebirds Network Site in 1999. The coast of YNNR is accreting annually with the mudflats moving about 50 to 200 meters seawards per year in the study area (Wang et al. 2006). Its original landscape comprises coastal salt marsh, so the variety of vegetation is poor and dominated by salt tolerant plants. The vegetation landscape had a typical landward succession sere type (Wan et al. 2001): (1) the pioneer species Spartina alterniflora dominates the elevated part of the intertidal zone; (2) a Suaeda salsa and Suaeda glauca community is dominant in the high tidal zone and (3) in the supratidal zone, Aeluropus littoralis and Phragmites australis are prevalent. The original vegetation landscape of the YNNR was comprised of Suaeda salsa, Phragmites communis Trin and Imperata. In 1963 and 1979, common cordgrass (Spartina land anglica C.E. Hubbard) and smooth cordgrass (Spartina alterniflora Loisel) were introduced from England and the United States respectively, and after the 1990s, they became the two dominant plants of the intertidal zone in the YNNR (Li et al. 2005). 

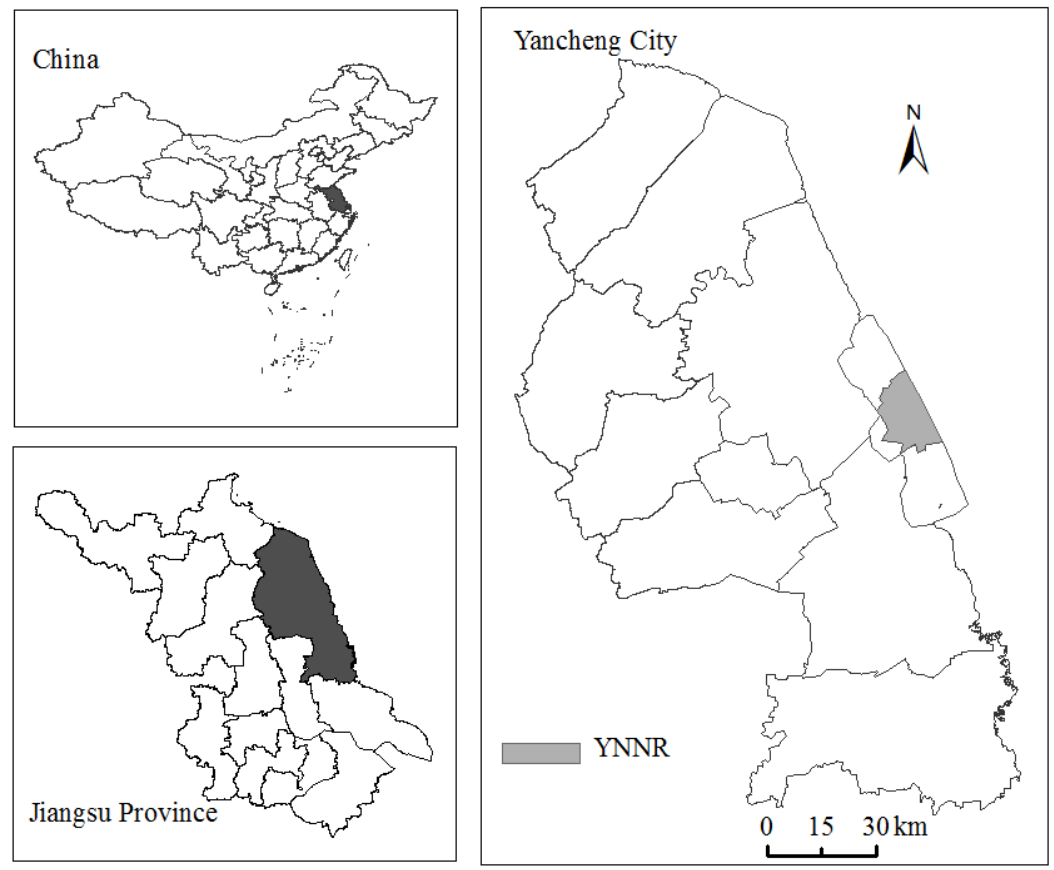

Fig.1 Location of the core area of YNNR

\section{Methods}

\section{Reconstruction of landscape history}

Landscape types of vegetation were derived from Landsat TM data obtained in June, 1992; May, 2002; and April, 2011, respectively (Table 1). In order to highlight the evolution of vegetation landscape, classification of vegetation landscape was a main concern. A system of landscape classification was established in which landscapes were grouped into 4 categories: the grass land, the Suaeda land, the Spartina land and the mudflat. The mathods was conducted before in our researches (Wang et al, 2014). All image processing was undertaken using the image analysis software ENVI 4.7. A supervised classification merging the maximum likelihood classify (MLC) and normalized difference vegetation index (NDVI) was used to classify the images with a classification accuracy of above $85 \%$ for all classes.

Table 1. Data source for the Thematic Mapper (TM).

\begin{tabular}{llll}
\hline Type & TM & TM & TM \\
\hline Path & 119037 & 119037 & 119037 \\
Acquisition time & June 11, 1992; & May 20, 2002; & April 23, 2011 \\
Used band & $1,2,3,4,5,7$ & $1,2,3,4,5,7$ & $1,2,3,4,5,7$ \\
\hline
\end{tabular}

Landscape evolution was a relatively long time span. Under the condition of lack of long-term observation data, we used the "space for time substitution" method to test the impact of time on the relationships between landscape evolution and soil because the landscape evolution over large time scales are beyond the duration of normal observations. This method assumes that important events and processes are independent of space and time (Pickett 1989; Fukami and Wardle 2005). Thus, the landscape configuration in vegetation zones of different ages can represent the evolution of the landscape. Landscape evolution in YNNR was mainly decided by natural factors. Affected by the tidal process, the elevation, soil and hydrology in YNNR was changed by sedimentation with the result of landscape evolution. 


\section{Soil sampling}

In April 2011, we collected soil samples based on the age of vegetation, with a total of 54 samples being obtained. Each sample consisted of a $500 \mathrm{~g}$ mixture of soil from a $0-30 \mathrm{~cm}$ profile obtained with the quartering method. All samples were air-dried in the laboratory and then analyzed for soil organic matter (SOM), available phosphorous (AP), available potassium (AK), total nitrogen (TN), total phosphorus (TP) and soil salinity (SS). Soil moisture (SM) was measured in situ using a soil moisture sensor (PICO-BT, made in Germany), and represented in \%. SOM, AP, AN, AK, TN and TP are strong indicators of the soil fertility status, while SS indicates the degree of plant desalinization.

Soil nutrient properties were measured in triplicate samples according to spectrophotometric methods. Soil sample was air-dried, ground and screened though 100-mesh sieve before analyzing. SOM was determined using the hydrated heat-photoelectric colorimetry method, with $\mathrm{K}_{2} \mathrm{Cr}_{2} \mathrm{O}_{7}, \mathrm{H}_{2} \mathrm{SO}_{4}$ (analytical pure) and $\mathrm{C}_{6} \mathrm{H}_{12} \mathrm{O}_{6} \mathrm{H}_{2} \mathrm{O}$ (chemical pure) as chromogenic reagents. Soil AP was measured using the photoelectric colorimetry method, with $\mathrm{NaHCO}_{3}$ and $\mathrm{Mo}-\mathrm{Sb}-\mathrm{VC}$ as the chromogenic reagents. Soil AK was extracted from air-dried soil samples by shaking with $50 \mathrm{ml}$ ammonium acetate/acetic acid solution for 30 minutes, and then used the extract flame photometric method. TP was determinate by fusion-colorimetry, and TN was determinated by using the semimicro-Kjeldahl method (Zhai et al., 2006). The extract was filtered and the concentrations was determined with a continuous-flow analyzer (EASYCHEM, made in Italy).The measurement error was within $0.5 \mathrm{mg} / \mathrm{kg}$ for all nutrient properties. Data analysis

Data layers of different vegetation landscape were identified with vegetation age zones in order to test the effects of vegetation landscape age on soil. The age of vegetation landscape can be plotted against time series using remote sensing image.

The soil property data and vegetation landscape data were overlaid to determine the relationship in between based on a plot of the mean \pm SD. The statistical analysis software SPSS 22 for Windows (Chicago, USA) was applied for the data analysis in this study.

\section{Results}

\section{Temporal dynamics of vegetation landscape}

From the analysis of the vegetation distribution based on the remote sensing in the three separate years, it was found that the area of spartina land and grass land increased dramatically (from $16 \mathrm{~km}^{2}$ and 82 $\mathrm{km}^{2}$ in 1992 to $37 \mathrm{~km}^{2}$ and $89 \mathrm{~km}^{2}$ in 2002, and then to $57 \mathrm{~km}^{2}$ and $98 \mathrm{~km}^{2}$ in 2011 respectively). Suaeda land increased from $54 \mathrm{~km}^{2}$ in 1992 to $66 \mathrm{~km}^{2}$ in 2002 and then decreased severely to $32 \mathrm{~km}^{2}$ in 2011(Fig. 2). The width of vegetation landscape presented the same change trends as vegetation landscape speared ever father seawards. As Spartina was introduced into the area between 1960s and 1970s, the landscape and hydrogeomorphologic condition gradually changed because of the function in bank protecting, wave defending and silt promoting.
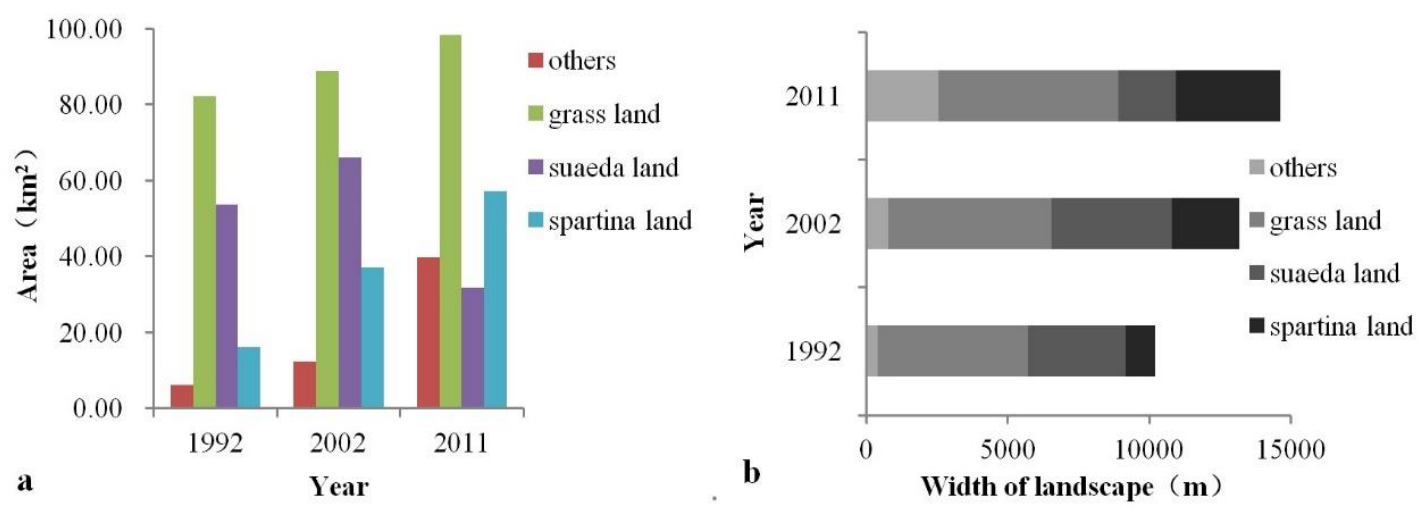

Fig. 2 The area (a) and the width (b) of vegetation landscape types in different years 


\section{Distinguish of space for time substitute}

Overlaying the maps of vegetation landscape, the characteristics of space for time can be identified by taking 10 years as the time scale. Six samples have belonged to the mudflat for more than 20 years, which can be abbreviated to G>20a. Six samples were located in mudflat from 1992 to 2002 and then substituted by Spartina land gradually, which means Spartina land in these six samples were less than 10 years (M<10a). In 1992, five samples were covered by muldflat, and then replaced by Spartina land, which means Spartina land in these five samples were more than 10 years and less than 20 years $(10 \mathrm{a}<\mathrm{M}<20 \mathrm{a})$. In the same way, eight samples can be classified to $10 \mathrm{a}<\mathrm{J}<20 \mathrm{a}$, twelve samples can be abbreviated to $\mathrm{J}>20 \mathrm{a}$, eight samples can be abbreviated to $10 \mathrm{a}<\mathrm{H}<20 \mathrm{a}$, nine samples can be abbreviated to $\mathrm{H}>20$ a (Fig. 3).
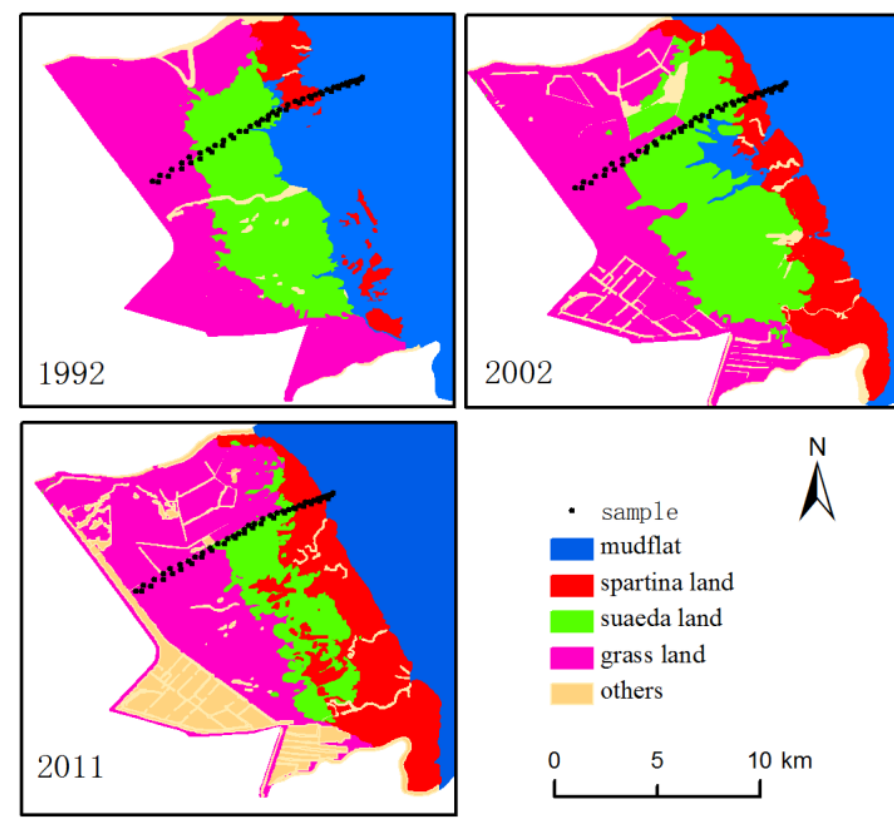

Fig. 3 Soil sampling sites and the change of landscape in YNNR from 1992-2011

\section{Current vegetation landscape and soil characteristic content}

With the samples of YNNR obtained during the investigation, the statistical analysis of the soil characteristic contents of the four current landscape types indicated that some of the soil indexes differ among the landscape (Table 2). The amounts of SM and SS were higher in the mudflat soils and lower in the grass and Suaeda land soils. The amounts of SOM, TN, TP, AP and AK in Suaeda and Spartina land were significantly higher than the corresponding amount in mudflat. The standard deviation (SD) of the soil properties in mudflat was higher than those for other landscape.

Table 2. Description of soil characteristics in the current landscape types.

\begin{tabular}{|c|c|c|c|c|c|c|c|}
\hline landscape & $\operatorname{SM}(\%)$ & $\mathrm{SS}(\%)$ & $\operatorname{SOM}(\%)$ & $\mathrm{TN}(\mathrm{mg} / \mathrm{kg})$ & $\mathrm{TP}(\mathrm{mg} / \mathrm{kg})$ & $\mathrm{AP}(\mathrm{mg} / \mathrm{kg})$ & $\mathrm{AK}(\mathrm{mg} / \mathrm{kg})$ \\
\hline mudflat $(\mathrm{G})$ & $55.23 \pm 15.27^{\mathrm{a}}$ & $1.18 \pm 0.61^{\mathrm{a}}$ & $0.38 \pm 0.11^{\mathrm{a}}$ & $93.51 \pm 48.96^{\mathrm{a}}$ & $821.42 \pm 320.17^{\mathrm{a}}$ & $4.58 \pm 2.56^{\mathrm{a}}$ & $97.38 \pm 46.20^{\mathrm{a}}$ \\
\hline spartina land (M) & $42.99 \pm 10.43^{\mathrm{a}}$ & $1.09 \pm 0.58^{\mathrm{b}}$ & $1.04 \pm 0.41^{\mathrm{b}}$ & $490.28 \pm 230.23^{b}$ & $830.48 \pm 133.16^{\mathrm{a}}$ & $14.81 \pm 9.33^{\mathrm{b}}$ & $197.85 \pm 86.11^{\mathrm{b}}$ \\
\hline suaeda land $(\mathrm{J})$ & $44.50 \pm 5.21^{\mathrm{b}}$ & $1.02 \pm 0.31^{\mathrm{b}}$ & $1.06 \pm 0.37^{\mathrm{b}}$ & $406.59 \pm 162.41^{b}$ & $638.59 \pm 66.17^{b}$ & $12.49 \pm 7.81^{\mathrm{b}}$ & $169.32 \pm 71.10^{\mathrm{b}}$ \\
\hline grass land $(\mathrm{H})$ & $37.83 \pm 2.15^{\mathrm{c}}$ & $0.54 \pm 0.27^{\mathrm{c}}$ & $1.00 \pm 0.26^{\mathrm{b}}$ & $310.51 \pm 138.11^{\mathrm{b}}$ & $600.23 \pm 63.03^{\mathrm{b}}$ & $7.74 \pm 2.61^{\mathrm{ac}}$ & $120.49 \pm 24.97^{\mathrm{a}}$ \\
\hline
\end{tabular}

\section{Soil properties during different evolution of landscape}

\section{Soil moisture and salinity response}

The amounts of $\mathrm{SM}$ in the stage of $\mathrm{G}>20 \mathrm{a}$ and $\mathrm{M}<10 \mathrm{a}$ were $55.23 \%$ and $52.37 \%$, which are significantly higher than that of other landscape evolution types. The amount of SM in $10 \mathrm{a}<\mathrm{J}<20 \mathrm{a}$ and $\mathrm{J}>20 \mathrm{a}$ were the second highest of the analyzed landscape evolution stages, followed by $\mathrm{H}>10 \mathrm{a}$ and then $\mathrm{H}>20 \mathrm{a}$. The 
soil salinity contents in $\mathrm{M}<10 \mathrm{a}$ and $10 \mathrm{a}<\mathrm{H}<20 \mathrm{a}$ were higher than that in $10 \mathrm{a}<\mathrm{M}<20 \mathrm{a}$ and $\mathrm{H}>20 \mathrm{a}$. The results indicated that the amounts of SM and SS in landscape were affected by the evolution years. According to Table 3, the SD of SM in G>20a and $\mathrm{J}>20 \mathrm{a}$ were higher, with values of 10.27 and 5.58, respectively. The trend of the SM was similar to that of the SS.

Table 3. Description of Soil moisture and salinity in the different landscape evolution stages

\begin{tabular}{llrrlll}
\hline Stages & \multicolumn{7}{l}{$\mathrm{SM}(\%)$} & \multicolumn{1}{l}{$\mathrm{SS}(\%)$} \\
\cline { 2 - 7 } & \multicolumn{1}{l}{$\operatorname{mean} \pm \mathrm{SD}$} & $\min$ & $\max$ & $\operatorname{mean} \pm \mathrm{SD}$ & $\min$ & $\max$ \\
$\mathrm{G}>20 \mathrm{a}$ & $55.23 \pm 10.27^{\mathrm{a}}$ & 40 & 90 & $1.23 \pm 0.62^{\mathrm{a}}$ & 1.03 & 1.38 \\
$\mathrm{M}<10 \mathrm{a}$ & $52.37 \pm 5.52^{\mathrm{a}}$ & 45.5 & 61.9 & $1.52 \pm 0.81^{\mathrm{a}}$ & 0.75 & 2.45 \\
$10 \mathrm{a}<\mathrm{M}<20 \mathrm{a}$ & $33.60 \pm 2.69^{\mathrm{b}}$ & 30.67 & 35.97 & $0.96 \pm 0.32^{\mathrm{b}}$ & 0.80 & 1.02 \\
$10 \mathrm{a}<\mathrm{J}<20 \mathrm{a}$ & $43.85 \pm 4.72^{\mathrm{b}}$ & 36.43 & 51.96 & $0.94 \pm 0.39^{\mathrm{b}}$ & 0.54 & 1.82 \\
$\mathrm{~J}>20 \mathrm{a}$ & $45.15 \pm 5.58^{\mathrm{b}}$ & 39.21 & 59.49 & $1.10 \pm 0.63^{\mathrm{b}}$ & 0.51 & 2.18 \\
$10 \mathrm{a}<\mathrm{H}<20 \mathrm{a}$ & $38.43 \pm 1.56^{\mathrm{c}}$ & 36.87 & 40 & $0.64 \pm 0.32^{\mathrm{b}}$ & 0.43 & 1.01 \\
$\mathrm{H}>20 \mathrm{a}$ & $37.23 \pm 2.31^{\mathrm{c}}$ & 34.36 & 41.29 & $0.44 \pm 0.26^{\mathrm{b}}$ & 0.14 & .87 \\
\hline
\end{tabular}

a, b and c mean values in columns are significantly different $(\mathrm{P}<0.05)$. Values are the mean \pm SD. The landscape of mudflat, spartina land, suaeda land and grass land can be abbreviated to $\mathrm{G}, \mathrm{M}, \mathrm{J}$ and $\mathrm{H}$.

\section{Soil organic matter, total nitrogen and total phosphorus response}

The soil organic matter (SOM) content in the various landscape evolution stages ranged from $0.26 \%$ $(\mathrm{G}>20 \mathrm{a})$ to $1.17 \%(10 \mathrm{a}<\mathrm{M}<20 \mathrm{a})$. The total nitrogen $(\mathrm{TN})$ content in $10 \mathrm{a}<\mathrm{J}<20 \mathrm{a}$ was significantly higher than the amounts in other stages, and the amounts of the total phosphorus (TP) in M<10a and $10 \mathrm{a}<\mathrm{M}<20 \mathrm{a}$ were high, while that in $\mathrm{G}>20 \mathrm{a}$ was the smallest among all the analyzed stages (Table 4).

Table 4. Description of SOM, TN and TP in the different landscape evolution stages

\begin{tabular}{|c|c|c|c|c|c|c|c|c|c|}
\hline \multirow[b]{3}{*}{$\mathrm{G}>20 \mathrm{a}$} & \multicolumn{3}{|l|}{$\operatorname{SOM}(\%)$} & \multicolumn{3}{|l|}{$\mathrm{TN}(\mathrm{mg} / \mathrm{kg})$} & \multicolumn{3}{|l|}{$\mathrm{TP}(\mathrm{mg} / \mathrm{kg})$} \\
\hline & mean \pm SD & $\min$ & $\max$ & mean \pm SD & $\min$ & $\max$ & mean \pm SD & $\min$ & $\max$ \\
\hline & $0.26 \pm 0.12^{\mathrm{a}}$ & 0.16 & 0.48 & $162.74 \pm 28.98^{\mathrm{a}}$ & 80.20 & 195.22 & $553.53 \pm 229.17 \mathrm{a}$ & 221.00 & 753.79 \\
\hline $\mathrm{M}<10 \mathrm{a}$ & $0.91 \pm 0.50^{\mathrm{b}}$ & 0.33 & 1.74 & $476.03 \pm 204.25^{\mathrm{b}}$ & 115.25 & 832.68 & $862.75 \pm 122.52 b$ & 713.29 & 935.48 \\
\hline $10 \mathrm{a}<\mathrm{M}<20 \mathrm{a}$ & $1.17 \pm 0.11^{\mathrm{b}}$ & 1.06 & 1.27 & $504.54 \pm 250.18^{\mathrm{b}}$ & 355.39 & 793.37 & $798.21 \pm 171.00 \mathrm{~b}$ & 678.37 & 994.03 \\
\hline $10 \mathrm{a}<\mathrm{J}<20 \mathrm{a}$ & $1.11 \pm 0.35^{\mathrm{b}}$ & 0.70 & 1.79 & $526.94 \pm 166.41^{\mathrm{b}}$ & 363.27 & 745.31 & $659.58 \pm 91.33 \mathrm{a}$ & 477.89 & 816.20 \\
\hline$J>20 a$ & $0.95 \pm 0.39^{b}$ & 0.00 & 1.70 & $286.23 \pm 65.03 \mathrm{c}$ & 204.14 & 454.07 & $617.60 \pm 41.47 \mathrm{a}$ & 496.69 & 678.37 \\
\hline $10 \mathrm{a}<\mathrm{H}<20 \mathrm{a}$ & $0.98 \pm 0.27^{\mathrm{b}}$ & 0.70 & 1.25 & $274.26 \pm 59.83 \mathrm{c}$ & 224.21 & 340.52 & $580.22 \pm 106.06 a$ & 459.10 & 656.44 \\
\hline $\mathrm{H}>20 \mathrm{a}$ & $1.01 \pm 0.27^{\mathrm{b}}$ & 0.56 & 1.58 & $346.77 \pm 149.52 \mathrm{c}$ & 219.91 & 684.39 & $620.25 \pm 46.91 \mathrm{a}$ & 521.75 & 687.77 \\
\hline
\end{tabular}

a, b and $\mathrm{c}$ mean values in columns are significantly different $(\mathrm{P}<0.05)$. Values are the mean \pm SD. The landscape of mudflat, spartina land, suaeda land and grass land can be abbreviated to $\mathrm{G}, \mathrm{M}, \mathrm{J}$ and $\mathrm{H}$.

\section{Available phosphorous and available potassium response}

The $10 \mathrm{a}<\mathrm{J}<20 \mathrm{a}$ soil had the highest AP content among all evolution stages. The $\mathrm{M}<10 \mathrm{a}$ and $10 \mathrm{a}<\mathrm{M}<20 \mathrm{a}$ have significantly higher AK content than the $10 \mathrm{a}<\mathrm{J}<20 \mathrm{a}$, as well as all the other landscape evolution stages. The landscape evolution can cause the AP content in the Suaeda land to decrease dramatically. Except for the SD of 10.01 for the AP in the $10 \mathrm{a}<\mathrm{J}<20 \mathrm{a}$ soil, the SD of the AP in the other landscape evolution stages were relatively small (1.25-6.65). However, the SD of the AK content ranged from 17.24 to 96.87 , and the mean values of the $\mathrm{AK}$ content ranged from 67.81 to $198.43 \mathrm{mg} / \mathrm{kg}$ (Table 5).

Table 5. Description of AP and AK in the different landscape evolution stages.

\begin{tabular}{lrrrrrr}
\hline & \multicolumn{7}{c}{$\mathrm{AK}(\mathrm{mg} / \mathrm{kg})$} & \multicolumn{1}{c}{$\mathrm{mg} / \mathrm{kg})$} \\
\cline { 2 - 7 } & \multicolumn{1}{c}{$\operatorname{mean} \pm \mathrm{SD}$} & \multicolumn{1}{c}{$\min$} & $\max$ & \multicolumn{1}{c}{$\operatorname{mean} \pm \mathrm{SD}$} & \multicolumn{1}{c}{$\min$} & $\max$ \\
$\mathrm{G}>20 \mathrm{a}$ & $3.13 \pm 1.56 \mathrm{a}$ & 1.01 & 5.96 & $67.81 \pm 30.20 \mathrm{a}$ & 42.02 & 100.84 \\
$\mathrm{M}<10 \mathrm{a}$ & $13.62 \pm 6.75 \mathrm{~b}$ & 5.11 & 35.71 & $198.43 \pm 96.87 \mathrm{~b}$ & 101.00 & 340.30 \\
$10 \mathrm{a}<\mathrm{M}<20 \mathrm{a}$ & $12.22 \pm 1.25 \mathrm{~b}$ & 10.84 & 13.28 & $197.27 \pm 78.75 \mathrm{~b}$ & 117.62 & 275.08 \\
$10 \mathrm{a}<\mathrm{J}<20 \mathrm{a}$ & $19.69 \pm 10.01 \mathrm{~b}$ & 9.52 & 33.68 & $175.78 \pm 64.64 \mathrm{~b}$ & 128.28 & 340.30 \\
$\mathrm{~J}>20 \mathrm{a}$ & $9.97 \pm 2.24 \mathrm{~b}$ & 5.96 & 13.46 & $162.86 \pm 76.50 \mathrm{~b}$ & 92.51 & 340.30 \\
$10 \mathrm{a}<\mathrm{H}<20 \mathrm{a}$ & $8.80 \pm 2.50 \mathrm{ab}$ & 6.05 & 10.93 & $118.67 \pm 17.24 \mathrm{ab}$ & 102.71 & 136.95 \\
$\mathrm{H}>20 \mathrm{a}$ & $6.68 \pm 2.55 \mathrm{ab}$ & 4.36 & 12.53 & $122.30 \pm 27.91 \mathrm{ab}$ & 84.38 & 170.47 \\
\hline
\end{tabular}

a, b and c mean values in columns are significantly different $(\mathrm{P}<0.05)$. Values are the mean \pm SD. The landscape of mudflat, spartina land, suaeda land and grass land can be abbreviated to $\mathrm{G}, \mathrm{M}, \mathrm{J}$ and $\mathrm{H}$. 


\section{Soil physicochemical indices and vegetation characteristics}

The data of plant height, average coverage, ground biomass and underground biomass were collected in the same place of soil samples. Compared to other vegetation communities, plant height, the ground and underground biomass of Spartina land were higher (Table 6). The average vegetation height of Spartina marsh, Suaeda marsh, and grass marsh were $1.50 \mathrm{~m}, 0.35 \mathrm{~m}$ and $0.70 \mathrm{~m}$, respectively. Their average coverage was $87.5,62.5$ and $92.5 \%$, respectively. The aboveground biomass of Spartina marsh was $1.14 \mathrm{~kg} / \mathrm{m} 2$, which was the highest value. The underground biomass of Spartina marsh was the highest value similarly.

Table 6. Characteristics of vegetation under different landscapes.

\begin{tabular}{lllll}
\hline & plant height $(\mathrm{cm})$ & average coverage $(\%)$ & ground biomass $\left(\mathrm{kg} / \mathrm{m}^{2}\right)$ & underground biomass $\left(\mathrm{kg} / \mathrm{m}^{2}\right)$ \\
$\mathrm{G}$ & 0 & 0 & 0 & 0 \\
$\mathrm{M}$ & 155 & 87.5 & 1.14 & 0.955 \\
$\mathrm{~J}$ & 35 & 62.5 & 0.135 & 0.08 \\
$\mathrm{H}$ & 69.5 & 92.5 & 0.44 & 0.565 \\
\hline
\end{tabular}

The relationship between the characteristic of plants and soil factors was shown in Table 7. Vegetation coverage had a significant positive correlation between soil organic matters. The correlation coefficient was 0.907. It also had a significant positive correlation between biomass and soil total nitrogen, including aboveground and underground biomass, which reflected the kind of interdependent relationship between vegetation characteristics and soil properties.

Table 7. Relationship between soil and vegetation characteristics.

\begin{tabular}{|c|c|c|c|c|c|c|c|}
\hline & SM & SS & SOM & $\mathrm{TN}$ & $\mathrm{TP}$ & $\mathrm{AP}$ & $\mathrm{AK}$ \\
\hline plant height & -0.520 & -0.195 & 0.566 & 0.694 & 0.384 & 0.656 & $0.877^{*}$ \\
\hline average coverage & $-0.861^{*}$ & -0.624 & $0.907^{* *}$ & 0.653 & -0.437 & 0.459 & 0.417 \\
\hline ground biomass & -0.568 & -0.294 & 0.506 & $0.907^{* *}$ & 0.391 & 0.587 & $0.893^{*}$ \\
\hline underground biomass & -0.479 & -0.224 & 0.451 & $0.875^{*}$ & 0.385 & 0.480 & $0.806 *$ \\
\hline
\end{tabular}

\section{Discussions}

We used the space for time substitution method to investigate the effects of time on landscape changes and found that grass land and Spartina land in the YNNR did show a generally increasing trend with time. Since the 2002, the reduction of Suaeda land has accelerated. The time of landscape evolution for one type can play an important role in the soil indicators. The longer time Spartina land settled, the lower content moisture, salinity of soil contained, the higher content of the soil nutrient contained, but the condition was just the reverse of Suaeda land. These findings are consistent with the temporal evolution trend observed for some soil properties ( $\mathrm{Li}$ et al. 2007; Sun et al. 2011) and for biodiversity (Shen et al. 2006; Sun et al. 2012).

Soil properties improved as landscape evolved from mudflats to vegetation, as indicated by soil fertility such as organic matter, total nitrogen, and total phosphorus, available phosphorous and available potassium. An earlier study of the YNNR also found that moisture and salinity concentration levels decreased after vegetation settled and evolved (Yao et al. 2009). Soil properties differed significantly among evolution types. The variation of $\mathrm{TN}$ in the $10 \mathrm{a}<\mathrm{J}<20 \mathrm{a}$ zone was much higher than in $\mathrm{J}>20 \mathrm{a}$ types. This could have occurred because the soil in $J>20$ a zone of our study area is rather old when compared to $10 \mathrm{a}<\mathrm{J}<20 \mathrm{a}$ and the soil nutrition easily lost with lower biomass of Suaeda land. Nutrient levels in the soil of Spartina land $(10 \mathrm{a}<\mathrm{M}<20 \mathrm{a}$ and $\mathrm{M}<10 \mathrm{a})$ were high when compared to that in the Suaeda land, which is consistent with a study of Spartina in YNNR that revealed that higher biomass can improve and maintain soil fertility (Ren et al. 2011). Because of none disturbing of any human 
activity, sampling sites was restricted along the unique road towards sea. The landscape is under the rule of belt shaped distribution along the coastline. The soil properties in the former studies (170$460 \mathrm{mg} / \mathrm{kg}$ for TN, Mao et al. 2009; 550-850mg/kg for TP, Zhong et al. 2010) seems to have similar level than the soil in our study area $(162-562 \mathrm{mg} / \mathrm{kg}$ for soil TN, and $553-862 \mathrm{mg} / \mathrm{kg}$ for TP, Table 4). However, when compared to the TN in surface sediments of agriculture nearby study area $(830 \mathrm{mg} / \mathrm{kg}$ ) (Mao et al. 2010), and the concentration of soil organic matter in our study area was much lower.

Landscape of vegetation evolution depends on soil as the important environmental conditions. On the contrary, the characteristics of the vegetation community inevitably affect soil properties. The soil in one stage not only reflects the result of interaction between vegetation community and the soil before, at the same time also determines soil foundation and the initial state of subsequent vegetation community (Pang et al. 2004). Coastal wetland vegetation characteristics have important influence on the tidal flat soil. The vegetation coverage, distribution area, especially plant biomass can change the soil properties (such as nutrient content) (Mao et al. 2010). Due to the differences of vegetation coverage, biomass, plant height, root length, the accumulated rate of soil nutrient in sediments are vary (Ren et al. 2011).

The growth of Spartina grass plays a controlling role in tidal flat sedimentation with the advantage to the nutrient storage (Mayer et al. 1988). There were the highest height, the highest coverage and the highest biomass of Spartina land. It had a significant positive correlation between biomass and soil total nitrogen.

Although the results from this study were obtained from two sampling strips, the trend of change in landscape with time and variation of soil properties under different evolution stages can be used as a reference for other part of YNNR. Therefore, the results presented herein will provide scientific support for future management. The results about effects of time and landscape evolution on the soil also contribute to the overall understanding of the relationship between landscape patterns and processes.

\section{Acknowledgements}

We thank Nerida Buckley and Zhang Xiaohong who greatly improved this manuscript with their constructive comments. And we also thank Natural Science Foundation of Yancheng Teachers University (No. 10YCKL029), Practice innovation training program for college students in Jiangsu Province (No. 201310324029Y), Natural Science Foundation of China (No. 31570459, 41401205), Natural Science Foundation of Jiangsu Province of China (No.15KJA170002, BK20140921), and a Project Funded by the Priority Academic Program Development of Jiangsu Higher Education Institutions (PAPD).

\section{References}

Roychoudhury, A.N., Cappellen, P.V., Kostka, J.E., Viollier, E. (2003). Kinetics of microbially mediated reaction: dissimilatory sulfate reduction in saltmarsh sediment (Sapelo Island, Georgia, USA). Estuarine Coastal \& Shelf Science 56(5-6): 1001-1010.

Bender, O., Boehmer, H.J., Jens, D., Schumacher, K.P. (2005). Analysis of landuse change in a sector of Upper Franconia (Bavaria, Germany) since 1850 using land register records. Landscape Ecology 20(2): 149-163.

Clarkson, B.D. (1998). Vegetation succession(1967-1989) on five recent montane lava flows, Mauna Loa, Hawii. New Zealand Journal of Ecology 22(1): 1-9.

El-Shikha, D.M., Waller, P., Hunsaker, D., Clarke, T., Barnes, E. (2007). Ground-based remote sensing for assessing water and nitrogen status of broccoli. Agriculture Water Management 92 (3), 183-193.

Fukami, T., Wardle, D.A. (2005). Long-term ecological dynamics: reciprocal insights from natural and anthropogenic gradients. Philosophical Transactions of the Royal Society B Biological Sciences 272(1577):2105-2115.

Gamboa, A.M., Galicia, L. (2011). Differential influence of land use/cover change on topsoil carbon and microbial activity in low-latitude temperate forests. Agriculture Ecosystem Environment 142 (3-4): 280-290. 
Gao, J.H., Ou, W.X., Yang, G.S., Wang, X.H., Xu, Q.K. (2005). Characteristics of tidal flat sediment at different ecologic zones, north Jiangsu Province. Donghai Marine Science 23(1): 40-46. (in Chinese)

Gosz, J.R. (1996). International long-term ecological research: priorities and opportunities. Trends in Ecology \& Evolution 11(10):444.

Grunwald, S., Reddy, K.R., Prenger, J.P., Fisher, M.M. (2007). Modeling of the spatial variability of biogeochemical soil properties in a freshwater ecosystem. Ecological Modelling 201(3-4), 521-535.

Li, J., Yang, X., Tong, Y. (2007). Progress on environmental effects of tidal flat reclamation. Progress in Geography 26(2):43-51. (in Chinese)

Li, X.Z., Sun, Y.G., Mander, U., He, Y.L. (2013). Effects of land use intensity on soil nutrient distribution after reclamation in an estuary landscape. Landscape Ecology 28(4): 699-707.

Li, Y.F., Zhu, X.D., Zou, X.Q. (2005). Study on Landscape Ecosystem of Coastal Wetlands in Yancheng, Jiangsu Province. Marine Science Bulletin 24(4): 46-51. (in Chinese)

Mao, Z.G., Gu, X.H., Liu, J.E., Ren, L.J., Wang, G.X. (2010). Evolvement of soilquality in saltmarshes and reclaimed farm lands in Yancheng coastal wetland. Chinese Journal of Applied Ecology 21(8): 1986-1992. (in Chinese)

Mayer, L.M., Macko, S.A. (1988). Cammen L. Provenance, concentrations and nature of sedimentary organic nitrogen in the Gulf of Maine. Marine Chemistry 25(3): 291-304.

Odland, A., DelMora, R. (2002). Thirteen years of wetland vegetation succession following a permanent drawdown, Myrkdalen Lake, Norway. Plant Ecology 162(2): 185-198.

Ouyang, W., Xu, Y.M., Hao, F.H., Wang, X.L., Siyang, C., Lin, C.Y. (2013). Effect of long-term agricultural cultivation and land use conversion on soil nutrient contents in the Sanjiang Plain. Catena 104(5): 243-250.

Pang, X.Y., Liu, Q., Liu, S.Q. (2004). Changes of soil fertility quality properties under subalpine spruce plantation in Western Sichuan. Acta Ecologica Sinica, 24(2): 261-267. (in Chinese)

Pellegrino, E., Di Bene, C., Tozzini, C., Bonari, E. (2011). Impact on soil quality of a 10-year-old short-rotation coppice poplar stand compared with intensive agricultural and uncultivated systems in a Mediterranean area. Agriculture Ecosystem Environ ment 140 (1-2), 245-254.

Pickett, S.T.A. (1989). Space-for-Time Substitution as an Alternative to Long-Term Studies. Springer New York 1989:110-135.

Ren, L.J., Wang, G.X., He, D., Mao, Z.G., Liu, J.E. (2011). Spatial distributions of soil organic matter in different vegetation zones of the Yancheng tidal flat. Advances in Marine Science 29 (1):54-62. (in Chinese)

Sean, P.P., Mary, A.B., Jonathan, H.G. (2002). Intertidal benthic resources of the Copper River Delta, Alaska, USA. Journal of Sea Resource 47: 13-23.

Shen, J., Hu, R., Li, M., Ding, P., Yu, M., Ding, B. ( 2006). Influence of reclamation on plant diversity of beach wetlands in Hangzhou Bay and Yueqing Bay in East China. Journal of Zhejiang University 33(3):324-328. (in Chinese)

Shen, Y.M., Fen, N.H., Zhou, Q. (2006) The status and its influence of reclamation on Jiangsu coast. Marine Sciences 30(10): 39-43. (in Chinese)

Sun, Y., Li, X., He, Y., Jia, Y., Ma, Z., Guo, W., Xin, Z. (2012). Impact factors on distribution and characteristics of natural plant community in reclamation zones of Changjiang River estuary. Chinese Geographical Science 22(2): 154-166. (in Chinese) 
Sun, Y., Li, X., Mander, U., He, Y., Jia, Y., Ma, Z., Guo, W., Xin, Z. (2011). Effect of reclamation time and land use on soil properties in Changjiang River Estuary, China. Chinese Geographical Science 21(4): 403-416. (in Chinese).

Wan, S.W., Qin, P., Li, Y. (2001). Wetland creation for rare waterfowl conservation: a project designed according to the principles of ecological succession. Ecological Engineering 18(1): 115-120.

Wang, A.J., Gao, S., Jia, J.J. (2006). Impact of Spartina alterniflora on sedimentary and morphological evolution of tidal salt marshes of Jiangsu,China. Acta Oceanologica Sinica, 28 (1): 92-99. (in Chinese)

Wang, C., Liu, H. Y., Zhang, Y., \& Li, Y. F. (2014). Classification of land-cover types in muddy tidal flat wetlands using remote sensing data. Journal of Applied Remote Sensing, 7(1), 073457.

Yao, C., Wan, S.W., Sun, D.L., Qin, P. (2009). Ecological mechanism s of vegetation succession of coastal wetland in Yancheng Nature Reserve. Acta Ecologica Sinica 29(5): 2203-2210.

Zhai, H.J., Cui, B.S., Zhao, X.S. (2006). Spatial variability and distribution of soil nutrient contents along different environmental gradients of Yilong lake shore. Acta Ecologica Sinica 26(1): 61-69.

Zhang, H.B., Liu, H.Y., Li, Y.F., An, J., Xue, X.Y., Hou, M.H. (2013). Spatial variation of soil moisture/salinity and the relationship with vegetation under natural conditions in Yancheng coastal wetland. Environmental Science 34(2): 540-546. (in Chinese)

Zhang, J.F., Zheng, Z., Jin, Y.X. (1990). Relation between vegetation succession and soil development. Journal of Wuhan Botanical Research 8: 325-334. (in Chinese)

Zhang, R.S. (1986). Characteristics of tidal current and sedimentation of suspended load on tidal mud flat in Jiangsu province. Oceanologia et Limnologia Sinica 17 (3):235-245. (in Chinese)

Zhang, R.S., Wang, X.Y. (1991). Tidal creek system on tidal mud flat of Jiangsu province. Acta Geographica Sinica, 46(2):195-206. (in Chinese)

Zhong, C.Q., Wang, J.X., Xing, W., Zhang, W.K. (2010). Effects of vegetation and hydrological conditions on the profile characteristics of TN, TP and OM in coastal salt marshes in northern Jiangsu Province. Journal of Beijing Forestry University 32 (3) 186-190. (in Chinese)

Zhu, D.K., Xu, T.G. (1982). The coast development and exploit of middle Jiangsu. Journal of Nanjing University (Natural Sciences) 3: 799-814. (in Chinese)

Zhu, H.G., Qin, P., Wang, H.(2004). Functional group classification and target species selection for Yancheng Nature Reserve, China. Biodiver Conserv 13:1335-1353.

Submitted: 11.05.2018

Accepted: 26.10 .2018 